Shevchenko O. M., Sych V. O. Cell reactions of inflammation focus in carrageenan secondary chronic inflammation on the background of substance $P$ blockade. Journal of Education, Health and Sport. 2020;10(11):199-211. eISSN 2391-8306. DOI http://dx.doi.org/10.12775/JEHS.2020.10.11.019

https://apcz.umk.pl/czasopisma/index.php/JEHS/article/view/JEHS.2020.10.11.019

https://zenodo.org/record/4294634

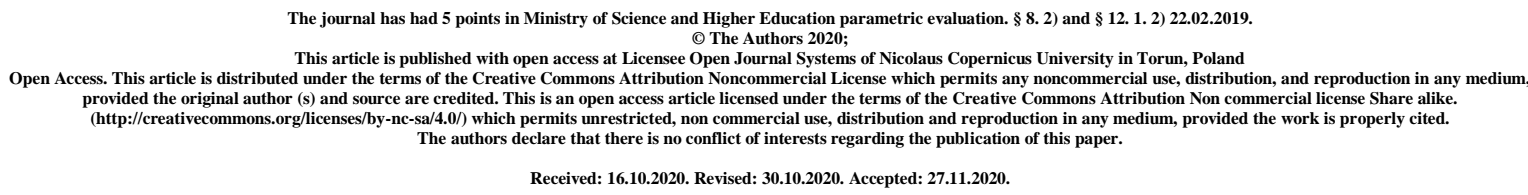

UDC: 616-002.2:577.114.4]-008.853-078:577.112.3.088.6

\title{
CELL REACTIONS OF INFLAMMATION FOCUS IN CARRAGEENAN SECONDARY CHRONIC INFLAMMATION ON THE BACKGROUND OF SUBSTANCE P BLOCKADE
}

\author{
O. M. Shevchenko, V. O. Sych
}

\section{Kharkiv National Medical University, Kharkiv, Ukraine}

\begin{abstract}
The aim of the study was to determine the features of cellular reactions of the inflammatory focus in carrageenan secondary chronic inflammation against the background of blockade of substance P. Experimental prospective controlled randomized study was performed on 132 WAG rats in series of 6 animals in each series: in control and for 6 hours; $1,2,3,5,7,10,14,21,28$ days in the conditions of the natural course of carrageenan inflammation and with the use of a pharmacological preparation, aprepitant - an inhibitor of NK-1 receptors. During the observation period of 6 hours to 3 days, neutrophilic, basophilic and eosinophilic leukocytes accumulate (phase of exudation of the inflammatory process). Peaks of neutrophils and basophils occur on day 2 (neutrophils - in the central parts of the inflammatory focus, basophils - in both areas, in the center and on the periphery) with a small predominance of the number of cells in the peripheral parts. The peak number of eosinophils occurs on day 1 and with a slight decrease on day 2 with their predominant location in peripheral areas. From 3-5 days the cellular composition of the infiltrate was characterized by a predominance of lymphocytes, monocytes, macrophages, plasma cells, tissue basophils,
\end{abstract}


cells of the fibroblastic series, which during blockade of substance $\mathrm{P}$ in a single amount appear for 2 days, predominate in peripheral areas (phases of proliferation and organization).

Key words: secondary chronic inflammation; focus of inflammation; mediators of inflammation.

\title{
КЛІТИНІ РЕАКЦІЇ ВОГНИЩА ЗАПАЛЕННЯ ЗА КАРАГІНЕНОВОГО ВТОРИННО-ХРОНІЧНОГО ЗАПАЛЕННЯ НА ФОНІ БЛОКАДИ СУБСТАНЦЇ̈ Р
}

\author{
О. М. Шевченко, В. О. Сич
}

\section{Харківський національний медичний університет}

\begin{abstract}
Резюме
Мета дослідження — визначити особливості клітинних реакцій вогнища запалення за карагіненового вторинно-хронічного запалення на фоні блокади субстанції Р. Експериментальне проспективне контрольоване рандомізоване дослідження проведено на 132 щурах лінії WAG у серіях по 6 тварин у кожній з серій: у контролі та протягом 6 годин; 1, 2, 3, 5, 7, 10, 14, 21, 28 діб в умовах природнього перебігу карагіненового запалення та із застосуванням фармакологічного препарату інгібітору НК-1 рецепторів апрепітанту. В терміни спостереження 6 год.-3 доби відбувається накопичення нейтрофільних, базофільних і еозинофільних лейкоцитів (фаза ексудації запального процесу). Піки вмісту нейтрофілів і базофілів мають місце на 2 добу (нейтрофілів - у центральних відділах осередку запалення, базофілів - в обох зонах, у центрі й на периферії) 3 невеликим переважанням кількості клітин у периферичних відділах. Пік кількості еозинофілів відбувається на 1 добу і з незначним зниженням на 2 добу з переважним їх розташуванням у периферичних зонах. 3 3-5 діб клітинний склад інфільтрату характеризується переважанням лімфоцитів, моноцитів, макрофагів, плазмоцитів, тканинних базофілів, клітин фібробластичного ряду, які за блокади субстанції Р в одиничній кількості з'являються вже на 2 добу, переважають в периферичних зонах (фази проліферації та організації).
\end{abstract}

Ключові слова: вторинно хронічне запалення; вогнище запалення; медіатори запалення. 
Introduction. Inflammation is the basis of most human diseases. In local inflammatory reactions, one of the key roles is played by intercellular interactions of the connective tissue continuum, mediated by neurokinin 1 receptors (NK1P), blockade of the function of substance $\mathrm{P}$ through which significantly affects the cellular composition of the inflammatory focus [1].

Despite the large number of studies on the functional activity of substance $\mathrm{P}$ under different conditions $[2,3,4,5,6]$, to date, there is little scientifically based information on the effects of its blocking in chronic inflammation and the impact on the cellular composition of its focus.

Aim: to determine the features of cellular reactions of the inflammatory focus in carrageenan secondary chronic inflammation on the background of blockade of substance P.

Materials and methods. An experimental prospective controlled randomized study was performed on $132 \mathrm{WAG}$ rats.

Stratification of animals in separate series was carried out in the amount of 6 individual rats per serium. Rats from control series remained intact from inflammation during the experiment or were only administered the preparation and were kept in unchanged standard conditions. Inflammationa in experimental rats was simulated according to the tasks for 6 hours and 1, 2, 3, 5, 7, 10, 14, 21, 28 days in the natural course and with the use of a pharmacological preparation - an inhibitor of NK-1 receptors of aprepitant.

The carrageenan model of inflammation was applied by introducing $10 \mathrm{mg}$ of $\alpha$ carrageenan (Sigma, USA) in $1 \mathrm{ml}$ of physiological splution [8] intramuscularly in the rat thigh under thiopental anesthesia. To inhibit the synthesis and effects of substance P the NK-1 receptor inhibitor aprepitant was used, which was administered intraperitoneally at a dose of $10 \mathrm{mg}$ dissolved in $1 \mathrm{ml}$ of isotonic sodium chloride solution daily throughout the experiment [7].

Animals were removed from the experiment by dislocation of the cervical vertebrae under overdose thiopental anesthesia (60 $\mathrm{mg} / \mathrm{kg}$ intraperitoneally).

The dynamics of the inflammatory process in the series was studied by counting inflammatory cell elements in a limited field of view $\left(1.6 \times 10^{-9} / \mathrm{m}^{2}\right)$ : in control series: in layers of fibrous connective tissue between bundles of muscle fibers; in series of inflammation modeling: in inflammatory infiltrates in the layers of fibrous connective tissue between the bundles of muscle fibers - in the center and on the periphery; in the presence of foci of necrosis and hemorrhage, granuloma - outside them. Histological and histochemical methods were performed according to the instructions in histological technique and histochemistry. 
Review microscopy with assessment of the cellular composition of the inflammatory focus, morphometry was performed using a microscope "Olympus BX-41" using the software "Olympus DP-Soft version 3.1".

All animal manipulations were carried out in accordance with national and international regulations. The study was approved by the Ethics and Bioethics Commission of Kharkiv National Medical University.

\section{Results and discussion}

The study of the dynamics of changes in the cellular composition of the inflammatory focus revealed that the accumulation of neutrophilic, basophilic and eosinophilic leukocytes is detected in the observation period of 6 hours to 3 days with peaks of their content: neutrophils and basophils - in 2 days; at the same time, neutrophils - in the central departments of the inflammatory center, basophils - in both zones (in the center and on the periphery) with a small predominance of the number of cells in the peripheral departments; eosinophils - for 1 day and with a slight decrease for 2 days, as well as with their predominant location in peripheral areas. This type of the cell composition with the predominance of these cellular elements indicates the phase of exudation of the inflammatory process.

From 3-5 days, the cellular composition of the infiltrate is characterized by a predominance of lymphocytes, monocytes, macrophages, plasma cells, tissue basophils, fibroblastic cells (which appear in a single amount of blockade of substance P for 2 days), which indicates the development of the proliferation phase. The highest concentration of these elements is generally observed in the peripheral zones and predominates during the blockade of substance $\mathrm{P}$, which, in turn, indicates the prevalence of proliferation and organization in peripheral areas.

The cellular dynamics of the inflammatory process during the natural course and in the series of inflammation against the background of blockade of substance P was studied.

In the inflammatory infiltrate of the femoral muscle tissue in the groups of natural inflammation and against the blockade of substance $\mathrm{P}$, the number of neutrophils, compared with the corresponding series of controls after 6 hours increases sharply, both in the center (Table 1) and on the periphery (Table 2) of the inflammatory focus, for 1 day increased and in a series of a natural course reached the peak for 2 days, in group of blockade of substance $\mathrm{P}$ the maximum value of level of neutrophils is on 1 day (Table 3 ).

In the following terms of observations there is a gradual decrease in the content of neutrophils: from 3 days in the natural course of inflammation, 2 days - in blockade of substance P (Table 4). 
Dynamics of changes in the center of cellular content of inflammatory focus and its natural course

(absolute cells count per $1.6 \times 10^{-9} \mathrm{~m}^{2}$ ), $M \pm m, n=6$

\begin{tabular}{|l|c|c|c|c|c|c|c|c|c|}
\hline Animal series & Neutrophiles & Basophiles & Eosinophiles & Lymphocytes & Monocytes & Plasmocytes & Macrophages & $\begin{array}{c}\text { Tissue } \\
\text { basophiles }\end{array}$ & Fibroblasts \\
& & & & & & & & \\
\hline Control & $0.31 \pm 0.42$ & $0.28 \pm 0.40$ & $0.33 \pm 0.44$ & $0.61 \pm 0.54$ & $0.58 \pm 0.49$ & $0.22 \pm 0.35$ & $0.19 \pm 0.31$ & $0.28 \pm 0.40$ & - \\
\hline 6 hours & $7.86 \pm 1.82$ & $5.50 \pm 1.69$ & $5.08 \pm 1.77$ & $5.06 \pm 1.29$ & $4.61 \pm 1.20$ & $4.83 \pm 1.46$ & $1.19 \pm 0.31$ & $0.89 \pm 0.49$ & - \\
\hline 1 day & $10.33 \pm 2.26$ & $6.92 \pm 1.70$ & $9.19 \pm 1.80$ & $6.28 \pm 1.50$ & $5.97 \pm 1.53$ & $7.69 \pm 1.73$ & $1.56 \pm 0.62$ & $1.22 \pm 0.54$ & - \\
\hline 2 days & $11.58 \pm 1.53$ & $8.78 \pm 1.23$ & $8.97 \pm 1.31$ & $8.03 \pm 1.42$ & $6.94 \pm 1.12$ & $8.28 \pm 1.33$ & $1.92 \pm 0.66$ & $1.56 \pm 0.67$ & - \\
\hline 3 days & $9.06 \pm 1.24$ & $7.86 \pm 1.15$ & $7.86 \pm 0.99$ & $8.44 \pm 0.94$ & $7.58 \pm 0.93$ & $8.97 \pm 0.98$ & $3.06 \pm 0.80$ & $2.28 \pm 0.77$ & $0.25 \pm 0.38$ \\
\hline 5 days & $7.28 \pm 1.46$ & $5.44 \pm 1.14$ & $4.25 \pm 1.04$ & $6.19 \pm 1.27$ & $8.47 \pm 1.50$ & $9.64 \pm 1.21$ & $4.14 \pm 1.45$ & $2.53 \pm 0.97$ & $0.33 \pm 0.44$ \\
\hline 7 days & $4.17 \pm 0.67$ & $2.28 \pm 0.84$ & $2.53 \pm 0.86$ & $3.03 \pm 0.87$ & $4.36 \pm 1.75$ & $4.56 \pm 1.27$ & $5.31 \pm 1.19$ & $3.03 \pm 0.92$ & $1.58 \pm 0.58$ \\
\hline 10 days & $3.53 \pm 1.25$ & $1.89 \pm 0.54$ & $2.11 \pm 0.55$ & $2.64 \pm 0.96$ & $4.64 \pm 1.53$ & $3.94 \pm 2.05$ & $6.06 \pm 1.39$ & $4.42 \pm 1.25$ & $3.06 \pm 0.74$ \\
\hline 14 days & $2.53 \pm 0.80$ & $1.56 \pm 0.64$ & $1.78 \pm 0.76$ & $2.81 \pm 0.75$ & $4.92 \pm 1.49$ & $2.53 \pm 0.86$ & $6.53 \pm 1.94$ & $3.67 \pm 1.41$ & $4.33 \pm 1.17$ \\
\hline 21 days & $0.69 \pm 0.42$ & $0.78 \pm 0.35$ & $0.64 \pm 0.46$ & $1.22 \pm 0.65$ & $3.57 \pm 1.48$ & $1.86 \pm 0.67$ & $5.14 \pm 1.16$ & $2.28 \pm 0.86$ & $5.17 \pm 0.98$ \\
\hline 28 days & $0.53 \pm 0.50$ & $0.39 \pm 0.48$ & $0.44 \pm 0.49$ & $1.11 \pm 0.60$ & $1.03 \pm 0.43$ & $1.03 \pm 0.43$ & $4.47 \pm 1.08$ & $1.69 \pm 0.66$ & $5.89 \pm 1.13$ \\
\hline
\end{tabular}


Dynamics of changes in the periphery of cellular content of inflammatory focus and its natural course

(absolute cells count per $1.6 \times 10^{-9} \mathrm{~m}^{2}$ ), $M \pm m, n=6$

\begin{tabular}{|c|c|c|c|c|c|c|c|c|c|}
\hline Animal series & Neutrophiles & Basophiles & Eosinophiles & Lymphocytes & Monocytes & Plasmocytes & Macrophages & $\begin{array}{c}\text { Tissue } \\
\text { basophiles }\end{array}$ & Fibroblasts \\
\hline Control & $0.31 \pm 0.42$ & $0.28 \pm 0.40$ & $0.33 \pm 0.44$ & $0.61 \pm 0.54$ & $0.58 \pm 0.49$ & $0.22 \pm 0.35$ & $0.19 \pm 0.31$ & $0.28 \pm 0.40$ & - \\
\hline 6 hours & $7.31 \pm 1.90$ & $5.61 \pm 1.24$ & $5.47 \pm 1.58$ & $5.14 \pm 1.59$ & $4.86 \pm 1.33$ & $5.06 \pm 1.56$ & $1.36 \pm 0.48$ & $1.72 \pm 0.68$ & - \\
\hline 1 day & $9.69 \pm 1.55$ & $7.11 \pm 1.69$ & $9.89 \pm 2.23$ & $6.42 \pm 1.38$ & $6.14 \pm 1.17$ & $7.53 \pm 1.83$ & $1.78 \pm 0.69$ & $2.03 \pm 0.87$ & - \\
\hline 2 days & $10.97 \pm 1.42$ & $9.31 \pm 1.23$ & $9.47 \pm 1.52$ & $9.06 \pm 1.35$ & $7.33 \pm 1.30$ & $7.92 \pm 1.11$ & $2.28 \pm 0.52$ & $2.28 \pm 0.69$ & - \\
\hline 3 days & $8.86 \pm 1.15$ & $8.03 \pm 1.15$ & $7.56 \pm 0.98$ & $11.61 \pm 2.42$ & $10.22 \pm 2.04$ & $9.42 \pm 1.26$ & $5.83 \pm 0.86$ & $4.03 \pm 0.98$ & $0.42 \pm 0.49$ \\
\hline 5 days & $6.94 \pm 1.29$ & $5.14 \pm 1.23$ & $4.75 \pm 1.10$ & $15.33 \pm 3.04$ & $11.58 \pm 1.77$ & $10.31 \pm 1.40$ & $6.69 \pm 1.40$ & $5.03 \pm 1.37$ & $2.53 \pm 0.83$ \\
\hline 7 days & $4.58 \pm 0.85$ & $3.69 \pm 0.82$ & $4.03 \pm 0.76$ & $16.89 \pm 3.99$ & $12.03 \pm 1.59$ & $8.61 \pm 1.72$ & $11.03 \pm 1.09$ & $6.22 \pm 1.38$ & $2.72 \pm 0.77$ \\
\hline 10 days & $4.03 \pm 0.81$ & $3.47 \pm 0.78$ & $3.56 \pm 1.11$ & $15.97 \pm 3.59$ & $12.58 \pm 1.96$ & $9.11 \pm 1.14$ & $11.58 \pm 1.94$ & $6.64 \pm 1.39$ & $8.17 \pm 1.85$ \\
\hline 14 days & $3.03 \pm 0.70$ & $2.97 \pm 0.98$ & $3.03 \pm 0.92$ & $15.56 \pm 3.14$ & $11.94 \pm 2.06$ & $8.22 \pm 1.38$ & $13.97 \pm 1.64$ & $7.06 \pm 1.74$ & $10.22 \pm 1.30$ \\
\hline 21 days & $1.11 \pm 0.50$ & $1.19 \pm 0.45$ & $1.17 \pm 0.47$ & $14.94 \pm 3.12$ & $9.03 \pm 0.87$ & $7.28 \pm 1.56$ & $14.89 \pm 2.01$ & $6.22 \pm 1.41$ & $12.47 \pm 1.19$ \\
\hline 28 days & $0.42 \pm 0.49$ & $0.33 \pm 0.44$ & $0.56 \pm 0.49$ & $15.03 \pm 2.47$ & $8.11 \pm 0.98$ & $6.58 \pm 1.78$ & $15.31 \pm 2.25$ & $6.53 \pm 1.59$ & $13.06 \pm 1.52$ \\
\hline
\end{tabular}


Dynamics of changes in the center of cellular content of inflammatory focus at the blockage of substance $P$

(absolute cells count per $1.6 \times 10^{-9} \mathrm{~m}^{2}$ ), $\mathrm{M} \pm \mathrm{m}, \mathrm{n}=6$

\begin{tabular}{|c|c|c|c|c|c|c|c|c|c|}
\hline Animal series & Neutrophiles & Basophiles & Eosinophiles & Lymphocytes & Monocytes & Plasmocytes & Macrophages & $\begin{array}{c}\text { Tissue } \\
\text { basophiles }\end{array}$ & Fibroblasts \\
\hline Control & $0.44 \pm 0.49$ & $0.28 \pm 0.40$ & $0.69 \pm 0.50$ & $0.89 \pm 0.54$ & $0.83 \pm 0.56$ & $0.47 \pm 0.50$ & $0.44 \pm 0.49$ & $0.42 \pm 0.49$ & - \\
\hline 6 hours & $7.61 \pm 1.50$ & $5.89 \pm 1.19$ & $6.03 \pm 1.53$ & $5.53 \pm 1.36$ & $4.69 \pm 1.21$ & $4.94 \pm 1.56$ & $1.22 \pm 0.35$ & $0.92 \pm 0.31$ & - \\
\hline 1 day & $9.72 \pm 1.97$ & $7.31 \pm 1.43$ & $9.64 \pm 1.71$ & $6.33 \pm 1.37$ & $6.08 \pm 1.48$ & $7.78 \pm 1.29$ & $1.61 \pm 0.58$ & $1.31 \pm 0.56$ & - \\
\hline 2 days & $7.75 \pm 1.10$ & $8.22 \pm 1.37$ & $8.53 \pm 1.48$ & $8.42 \pm 1.25$ & $7.67 \pm 1.59$ & $8.36 \pm 1.35$ & $2.28 \pm 0.81$ & $2.17 \pm 0.56$ & $0.19 \pm 0.31$ \\
\hline 3 days & $7.06 \pm 1.28$ & $7.94 \pm 1.34$ & $8.06 \pm 1.34$ & $8.92 \pm 1.40$ & $8.28 \pm 1.14$ & $9.33 \pm 1.37$ & $3.61 \pm 1.10$ & $3.19 \pm 1.00$ & $0.33 \pm 0.44$ \\
\hline 5 days & $5.39 \pm 1.17$ & $4.67 \pm 1.43$ & $3.97 \pm 1.10$ & $5.61 \pm 1.24$ & $9.03 \pm 1.42$ & $9.03 \pm 1.03$ & $5.03 \pm 1.76$ & $4.14 \pm 1.22$ & $1.50 \pm 0.58$ \\
\hline 7 days & $4.03 \pm 0.65$ & $2.56 \pm 0.83$ & $2.47 \pm 0.86$ & $4.03 \pm 1.09$ & $4.53 \pm 1.33$ & $4.97 \pm 1.26$ & $5.53 \pm 1.19$ & $3.53 \pm 1.48$ & $1.72 \pm 0.68$ \\
\hline 10 days & $3.42 \pm 1.00$ & $2.08 \pm 0.62$ & $2.03 \pm 0.49$ & $3.03 \pm 0.81$ & $5.03 \pm 1.26$ & $4.53 \pm 1.44$ & $6.56 \pm 1.24$ & $4.97 \pm 1.75$ & $3.25 \pm 0.83$ \\
\hline 14 days & $1.97 \pm 0.71$ & $1.06 \pm 0.47$ & $1.11 \pm 0.20$ & $2.42 \pm 0.71$ & $4.53 \pm 1.22$ & $2.97 \pm 0.93$ & $6.94 \pm 1.51$ & $4.03 \pm 1.59$ & $6.06 \pm 1.13$ \\
\hline 21 days & $0.58 \pm 0.49$ & $0.81 \pm 0.40$ & $0.53 \pm 0.50$ & $1.53 \pm 0.78$ & $3.72 \pm 1.20$ & $2.03 \pm 0.54$ & $5.36 \pm 1.14$ & $2.47 \pm 0.83$ & $6.81 \pm 1.14$ \\
\hline 28 days & $0.47 \pm 0.50$ & $0.53 \pm 0.50$ & $0.39 \pm 0.48$ & $1.33 \pm 0.74$ & $2.03 \pm 0.65$ & $1.42 \pm 0.49$ & $4.28 \pm 1.09$ & $2.03 \pm 0.65$ & $6.89 \pm 1.29$ \\
\hline
\end{tabular}


Dynamics of changes in the periphery of cellular content of inflammatory focus at the blockage of substance $P$

(absolute cells count per $1.6 \times 10^{-9} \mathrm{~m}^{2}$ ), $\mathrm{M} \pm \mathrm{m}, \mathrm{n}=6$

\begin{tabular}{|c|c|c|c|c|c|c|c|c|c|}
\hline Animal series & Neutrophiles & Basophiles & Eosinophiles & Lymphocytes & Monocytes & Plasmocytes & Macrophages & $\begin{array}{c}\text { Tissue } \\
\text { basophiles }\end{array}$ & Fibroblasts \\
\hline Control & $0.44 \pm 0.49$ & $0.28 \pm 0.40$ & $0.69 \pm 0.50$ & $0.89 \pm 0.54$ & $0.83 \pm 0.56$ & $0.47 \pm 0.50$ & $0.44 \pm 0.49$ & $0.42 \pm 0.49$ & $0.44 \pm 0.49$ \\
\hline 6 hours & $7.53 \pm 1.69$ & $6.11 \pm 1.62$ & $6.42 \pm 1.65$ & $5.69 \pm 1.21$ & $4.81 \pm 1.44$ & $5.08 \pm 1.22$ & $1.39 \pm 0.50$ & $1.78 \pm 0.65$ & - \\
\hline 1 day & $9.39 \pm 1.71$ & $7.56 \pm 1.39$ & $10.03 \pm 1.92$ & $6.56 \pm 1.39$ & $6.36 \pm 1.58$ & $7.92 \pm 1.26$ & $1.81 \pm 0.58$ & $2.22 \pm 0.83$ & - \\
\hline 2 days & $7.25 \pm 1.31$ & $8.67 \pm 1.63$ & $8.86 \pm 1.46$ & $9.47 \pm 1.44$ & $7.94 \pm 1.13$ & $8.06 \pm 1.23$ & $2.64 \pm 0.71$ & $2.39 \pm 0.71$ & $0.31 \pm 0.42$ \\
\hline 3 days & $6.67 \pm 1.19$ & $8.28 \pm 1.39$ & $8.22 \pm 1.14$ & $12.06 \pm 1.85$ & $11.06 \pm 2.12$ & $9.31 \pm 1.76$ & $6.22 \pm 1.10$ & $4.11 \pm 1.14$ & $0.5 \pm 0.5$ \\
\hline 5 days & $4.94 \pm 1.29$ & $5.03 \pm 1.31$ & $4.22 \pm 1.31$ & $16.19 \pm 2.69$ & $12.03 \pm 1.81$ & $10.14 \pm 1.53$ & $9.39 \pm 2.22$ & $6.11 \pm 1.13$ & $2.94 \pm 0.90$ \\
\hline 7 days & $4.39 \pm 1.09$ & $3.53 \pm 0.94$ & $3.94 \pm 0.85$ & $17.39 \pm 2.79$ & $12.53 \pm 2.00$ & $9.03 \pm 1.26$ & $11.56 \pm 1.91$ & $6.56 \pm 1.69$ & $3.31 \pm 0.73$ \\
\hline 10 days & $3.94 \pm 1.06$ & $3.31 \pm 0.73$ & $3.33 \pm 0.83$ & $16.47 \pm 2.75$ & $13.03 \pm 2.47$ & $9.94 \pm 1.56$ & $12.08 \pm 2.04$ & $7.03 \pm 1.31$ & $9.14 \pm 1.55$ \\
\hline 14 days & $2.53 \pm 0.94$ & $2.06 \pm 0.58$ & $2.47 \pm 0.74$ & $15.78 \pm 3.02$ & $12.08 \pm 1.76$ & $9.08 \pm 1.72$ & $14.53 \pm 2.11$ & $6.92 \pm 1.44$ & $12.14 \pm 1.17$ \\
\hline 21 days & $1.03 \pm 0.32$ & $1.22 \pm 0.56$ & $1.06 \pm 0.37$ & $15.28 \pm 2.48$ & $10.03 \pm 1.25$ & $10.06 \pm 1.40$ & $15.06 \pm 1.51$ & $6.53 \pm 1.14$ & $13.22 \pm 1.69$ \\
\hline 28 days & $0.39 \pm 0.48$ & $0.31 \pm 0.42$ & $0.44 \pm 0.49$ & $15.14 \pm 3.35$ & $9.03 \pm 1.04$ & $6.97 \pm 1.91$ & $15.69 \pm 2.38$ & $6.42 \pm 1.32$ & $14.17 \pm 1.44$ \\
\hline
\end{tabular}


In both groups in terms of observation from 6 hours to 5 days the number of neutrophils in the center slightly exceeds in the following terms - contrary, less that is explained both by change of qualitative cellular structure, and by rarefaction of an inflammatory infiltrate in the central locations.

The dynamics of changes in the content of basophilic leukocytes in the foci of inflammation of the studied groups is also characterized by its increase from 6 hours of observation, reaching a maximum in the natural course of inflammation and blockade of substance $\mathrm{P}$ for 2 days, and a corresponding decrease from 3 days.

There is a slight predominance of basophils at the periphery of the inflammatory infiltrate in both groups in the observation period of 6 hours - 5 days, and quite significant in terms of 7-14 days, which can also be explained by the rarefaction of the cell composition in the central parts of the inflammatory infiltrate.

The peak increase in the number of eosinophilic leukocytes in both study groups is the observation period of 1 day. In the following terms the number of eosinophils gradually decreased, in all terms (except for 3 days of supervision over a natural course of an inflammation) eosinophils were mainly located on the periphery of the center of an inflammation.

The dynamics of changes in the content of lymphocytes differs from the above: the number of lymphocytes both naturally and under blockade of substance P, up to 3 days in the center and on the periphery of inflammatory infiltrates gradually increased, and from 5 days in the centers of foci there was a gradual decrease. In the peripheral departments, the number of lymphocytes increased, reaching a maximum on day 7 , followed by a slight gradual decrease, starting with day 10 of observation. In addition, in almost all terms of observation, the predominance of the content of lymphocytes in the blockade of substance $P$.

The dynamics of changes in the content of monocytes resembles the dynamics of changes in the content of lymphocytes, however, the maximum number of counted cells in the center of the foci is reached on the 5th day of observation.

On the periphery, the number of monocytes on the 3rd day and in subsequent followup significantly exceeded the number in the center, their maximum content is in 10 days and gradually decreased from 14 days. And just like lymphocytes, the number of monocytes is slightly higher than in the blockade of substance $\mathrm{P}$.

The dynamics of changes in the level of plasma cells is similar to the dynamics of changes in the content of lymphocytes and monocytes, however, on day 1 during the natural 
course of inflammation and on day 3 in both groups the number of counted cells in the center of foci was slightly higher than on the periphery.

The maximum number of plasma cells in the centers of inflammatory infiltrates in the natural course of inflammation reached in 5 days, and during the blockade of substance $\mathrm{P}-3$, followed by a sharp decrease in their level from the 7th day (due to transformation of cellular infiltrate). In peripheral areas the maximum level of plasma cells were on 5th day with their gradual uneven decrease. From 7 days to the last observation period of 28 days there was a significant predominance of the number of plasma cells in the periphery. And yet, like lymphocytes and monocytes, plasma cells in greater numbers were detected mainly by blockade of substance P.

In the dynamics of changes in the level of macrophages, a synchronous gradual increase in the number of cells was detected both in the center and on the periphery of inflammatory infiltrates up to 2 days.

On the 3rd day, with a continuing gradual increase in the number of macrophages in the central departments (up to 14 days, followed by their gradual decrease), in the peripheral departments there was a rather sharp and progressive increase in the number of counted elements with a maximum of 28 days. During the blockade of substance $\mathrm{P}$ in all periods of observation, the number of macrophages was greater than during the natural course of inflammation.

Tissue basophils were also detected in all observation periods in both groups with their predominant location on the periphery of the inflammatory focus, with their gradual increase mostly in the peripheral parts of inflammatory infiltrates, the number of tissue basophils in the central parts didn't have significant differences.

However, their content, both in the center and on the periphery of inflammatory infiltrates, during the blockade of substance $\mathrm{P}$ was higher than during the natural course of inflammation.

Cells of the fibroblastic series begin to appear in the natural course of inflammation from 3, and during the blockade of substance $\mathrm{P}$ - from 2 days of observation, gradually increasing in the central and peripheral parts of inflammatory foci up to 7 days, 10 days in peripheral areas there was a sharp increase in the number of calculated elements with their subsequent gradual growth and a maximum of 28 days.

Cells of the fibroblastic series, as well as the lymphoid-macrophage elements described above, were found in greater numbers by blockade of substance P. 
Thus, the features of cellular reactions of the inflammatory focus in carrageenan secondary-chronic inflammation against the background of blockade of substance $\mathrm{P}$ were identified. This can be used as a criterion for assessing the parameters of the inflammatory response [9]

Cellular responses in the inflammatory focus were associated with the relationship between different types of immune cells and the functionality of substance P. Macrophages are likely to join the inflammatory process only when it is severe. It is known that macrophages of lung tissue of smokers express 3 times more NK1P than macrophages of the control group [10], and a significant increase in their number on the macrophages of the small arteries of the meninges [11]. The researchers concluded that tobacco smoke causes hyperexpression of NK1P by stimulating nicotinic acetylcholine receptors, which was minimized by a specific inhibitor. [12].

Neutrophils under the influence of substance P secrete superoxide and chemokines, as well as increase their phagocytic properties [2]. In a study by A. Ahluwalia et al. (1998) neutrophils deprived of the NK 1 receptor were $62 \%$ less responsive to IL-1 $\beta$-induced chemotaxis [13].

Eosinophils also express NK1P, but in small amounts, regardless of the presence of atopy, as shown by M. Raap et al. [3].

Natural killers, which also contain NK1P, under the influence of substance P more actively synthesize interferon gamma, cytotoxic molecules (perforin, granzyme) and natural cytotoxic receptors (p46) $[4,14]$.

T-lymphocytes also carry on their surface NK1P, the stimulation of which leads primarily to the expression of NF-k $\beta$ and the synthesis of IL-2, which prolongs the life of CD4 and CD8 cells [15]. Under physiological conditions, T-lymphocytes are stimulated primarily by dendritic cells, which inflames the processes of cellular cytotoxicity [15]. The role of T-lymphocytes, as well as macrophages is wider: under the influence of IL-12, IL-23 in these cells may increase the expression of NK1P [5, 16]. TNF in turn increases the duration of binding of substance $\mathrm{P}$ to its receptor, which increases the activity of the complex [16]. Another effect of substance $\mathrm{P}$ on $\mathrm{T}$ lymphocytes is the stimulation of the production of IL-17 and interferon gamma, which intensifies inflammation [16]. Proliferation of T-lymphocytes under the influence of substance $P$ is probably interrelated with the action of IL-2 [6]. 


\section{Conclusions:}

1. In the period of observation of 6 hours-3 days there is an accumulation of neutrophilic, basophilic and eosinophilic leukocytes (phase of exudation of the inflammatory process).

2. Peaks of neutrophils and basophils occur on day 2 (neutrophils - in the central foci of inflammation, basophils - in both areas, in the center and on the periphery) with a small predominance of the number of cells in the peripheral parts.

3. The peak number of eosinophils occurs on day 1 and with a slight decrease on day 2 with their predominant location in peripheral areas.

4. From 3-5 days the cellular composition of the infiltrate is characterized by a predominance of lymphocytes, monocytes, macrophages, plasma cells, tissue basophils, cells of the fibroblastic series, which during blockade of substance $\mathrm{P}$ in a single number appear for 2 days predominate in peripheral areas (proliferation phase organizations).

\section{References}

1. Antagonism of NK-1R using aprepitant suppresses inflammatory response in rheumatoid arthritis fibroblast-like synoviocytes / X. Liu, Y. Zhu, W. Zheng, T. Qian, H. Wang, X. Hou // Artif Cells Nanomed Biotechnol. — 2019. — Vol. 47, No. 1. — P. 16281634.

2. Suvas S. Role of substance $\mathbf{P}$ neuropeptide in inflammation, wound healing, and tissue homeostasis // J. Immunol. — 2017. — Vol. 199, No. 5. - P. 1543-1552.

3. Substance P activates human eosinophils / M. Raap, U. Rüdrich, S. Ständer [et al.] // Exp. Dermatol. — 2015. — Vol. 24, No. 7. - P. 557-559.

4. Substance $P$ (SP) induces expression of functional corticotropin-releasing hormone receptor-1 (CRHR-1) in human mast cells / S. Asadi, K. D. Alysandratos, A. Angelidou [et al.] // J. Invest. Dermatol. - 2012. — Vol. 132, No. 2. — P. 324-329.

5. Interleukin-12 (IL-12) and IL-23 induction of substance $P$ synthesis in murine $T$ cells and macrophages is subject to IL-10 and transforming growth factor $\beta$ regulation / A. Blum, T. Setiawan, L. Hang [et al.] // Infect. Immun. — 2008. — Vol. 76, No. 8. - P. 36513656.

6. Neuropeptide substance $\mathrm{P}$ and the immune response / A. Mashaghi, A. Marmalidou, M. Tehrani [et al.] // Cell Mol. Life Sci. - 2016. - Vol. 73, No. 22. — P. $4249-4263$. 
7. An FDA approved neurokinin-1 receptor antagonist is effective in reducing intraabdominal adhesions when administered intraperitoneally, but not orally / R. Lim, J. M. Morrill, S. G. Prushik [et al.] // J. Gastrointest. Surg. — 2008. — Vol. 12. — P. 1754-1761. — doi: 10.1007/s11605-008-0634-4.

8. 8. Substantiation of the model of chronic (secondary chronic) inflammation / N. A. Klimenko, S. V. Tatarko, A. N. Shevchenko, G. I. Gubina-Vakulik // Experimental and clinical medicine. — 2007. — № 2. - P. 24-28. (in Russian)

9. Belogurova E. A. Inflammation / E. A. Belogurova, I. V. Budnikova. - SPb. : SZGMU Publishing House. II Mechnikov. — 2014. — 24 p. (in Russian)

10. Rameshwar P. Hematopoietic modulation by the tachykinins / P. Rameshwar, P. Gascón // Acta Haematol. — 1997 — Vol. 98, No. 2. — P. 59-64.

11. Effects of chronic tobacco smoking on the distribution of tachykinin receptors in rat pial arteries / N. V. Zakharchuk, V. M. Chertok, V. A. Nevzorova, E. Y. Gonchar // Bull Exp Biol Med. - 2017. — Vol. 163, No. 3. - P. 313-316.

12. Prenatal nicotinic exposure upregulates pulmonary C-fiber HK1P expression to prolong pulmonary C-fiber-mediated apneic response / L. Zhao, J. Zhuang, N. Zang [et al.] // Toxicol. Appl. Pharmacol. — 2016. — Vol. 290. — P. 107-115.

13. Impaired IL-1beta-induced neutrophil accumulation in tachykinin NK1 receptor knockout mice / A. Ahluwalia, C. De Felipe, J. O'Brien [et al.] // Br. J. Pharmacol. - 1998. - Vol. 124, No. 6. - P. 1013-1015.

14. Role of capsaicin-sensitive nerves and tachykinins in mast cell tryptase-induced inflammation of murine knees / É. Borbély, K. Sándor, A. Markovics [et al.] // Inflamm. Res. - 2016. - Vol. 65, No. 9. - P. 725-736.

15. The neurokinin 1 receptor and its agonists recruited at the DC-T cell synapse are necessary to promote the survival of activated T cells in vivo / A. T. Larregin, T. L. Sumpter, D. M. Rojas [et al.] // J. Immunol. — 2017. — Vol. 198, Suppl. 1. — P. 220.

16. Weinstock J. V. Substance $P$ and the regulation of inflammation in infections and inflammatory bowel disease // Acta. Physiol. (Oxf). — 2015. - Vol. 213, No. 2. - P. 453461. 